\title{
Rectus fascia colpopexy for post-hysterectomy vault prolapse: a valid option
}

\author{
Histerektomi sonrası vajinnal apikal prolapsus için rektus fasya kolpopeksisi: geçerli bir seçenek \\ Rajiv Mahendru \\ Department of Obs Gyn, Mmimsr, Mullana, Ambala, Haryana, India
}

\section{Abstract}

Objective: Considering the great variety of techniques and disagreement about the ideal route, there is a need for a safe, simple and effective method for the management of apical prolapse.

Material and Methods: Twenty seven cases of post- hysterectomy vault prolapse (twenty four following vaginal and three after total abdominal hysterectomy) were treated surgically by anterior abdominal wall colpopexy with autogenous rectus fascia strips.

Result: Except for minor complaints like- vomiting, fever and urinary retention in $3.7 \%$ cases each $(n=1)$, no major complications were encountered. Moreover, no recurrence, on follow-up thus far.

Conclusion: Using autogenous rectus fascia strips in anterior abdominal wall colpopexy is not only a simple, cheap and effective method of treating vault prolapse but is also devoid of any serious complications such as described with other techniques.

(J Turkish-German Gynecol Assoc 2010; 11: 69-72)

Key words: Vault Prolapse, rectus fascia, enterocoele

Received: 3 February, 2010

Accepted: 21 March, 2010

\section{Özet}

Amaç: Değişen birçok teknik ve yaygın kabul görmüş bir yöntem olmaması nedeniyle, apikal prolapsuslarda basit, güvenli ve etkin bir yönetime ihtiyaç vardır.

Gereç ve Yöntemler: Yirmi yedi post-histerektomi vajinal apeks prolapsusu olan (24 tanesi vajinal histerektomi, 3 tanesi de abdominal total histerektomi sonrası) vaka otolog rektus fasya şeriti kullanılarak abdominal kolpopeksi yöntemi ile opere edildiler.

Bulgular: Kusma, ateş, \%3.7 vakada $(\mathrm{n}=1)$ üriner retansiyon gibi minor yakınmaların yanında herhangi bir mjor komplikasyon gözlenmedi. Dahası, şu ana kadar izlemde herhangi bir rekürrens de görülmedi.

Sonuç: Otolog rektus fasyası kullanılarak uygulanan apikal prolapsus tedavisi sadece basit, ucuz ve etkin değil, aynı zamanda diğer yöntemlerde bildirilen major komplikasyonların görülmemesi nedeniyle tercih edilmesi gereken bir yöntemdir.

(J Turkish-German Gynecol Assoc 2010; 11: 69-72)

Anahtar kelimeler: Vajinal apikal prolapsus, rektus fasyası, enterosel

Geliş Tarihi: 03 Şubat 2010

Kabul Tarihi: 21 Mart 2010

\section{Introduction}

Post-hysterectomy apical (vault) prolapse is referred to as the descent of the vaginal vault/cuff scar below a point that is $2 \mathrm{~cm}$ less than the total vaginal length above the plane of the hymen (1). This condition is shown to follow $11.6 \%$ of hysterectomies performed vaginally for prolapse and $1.8 \%$ of those performed abdominally for other indications (2). Several surgical procedures have been described for the treatment of vault prolapse and, given the available evidence of complications and limitations of each, it is difficult to recommend one technique over the other (3). Regarding vault suspension to the anterior abdominal wall, the number of studies available are insufficient to assess its efficacy.

\section{Material and Methods}

In the period between Dec.2002 to Apr. 2005, 27 cases of vaginal vault prolapse were treated by the innovative technique described hereunder. 88.89\% $(n=24)$ had had undergone vaginal hysterectomy for genital prolapse and the remaining $11.11 \%(n=3)$ had apical prolapse developing after abdomi- nal hysterectomy for the indications of leiomyoma uteri in two cases and dysfunctional uterine bleeding in the other case. The mean time which elapsed from the previous surgery was 27 months, with the shortest being 11 months and the longest being 50 months. Two of these cases in the vaginal hysterectomy group had undergone prior surgery for vault prolapse-one had sacrocolpopexy 13 months previously, and the other had some vaginal procedure 27 months previously, for which there is no record available, but both of these developed recurrence. Mean age of our patients was 56.3 years, with the youngest and oldest being $33 \& 67$ years respectively. 19 patients belonged to a lower socio- economic strata out of which, 17 were labour class manual working women and two were routine housewives as also were five of the other group of 8 of middle income group. The remaining 3 were field health workers $(n=2)$ and school teacher $(n=1)$. Based on the quality of life, complaints, history, clinical examination (with classification according to the POP-Q system)-a questionnaire was filled for each patient. Six of the patients had stress incontinence (all after vaginal hysterectomy). The previous history of one patient included Pulmonary Tuberculosis for which she had had a full course of anti- 
tubercular treatment and at present was symptom free. Prior to surgery, the presence of chronic cough \& chronic constipation complaints were clearly addressed. Written informed consent was obtained from all the patients and the Institutional Ethical Committee approved the study. Clinical examination was conducted for the presence of enterocoele ( $n=6$-all of vaginal hysterctomy), cystocole $(n=9)$, rectocoele $(n=23)$ and, genuine stress incontinence $(n=6)$. Initially, bladder catheterisation was performed with a 16 french indwelling Foley's catheter followed by tight vaginal packing pre-operatively. Technique employed: transverse skin incision (Pfannenstiel) about $8 \mathrm{~cm}$ long at the level of the anterior superior iliac spine. The rectus sheath was exposed by separating the subcutaneous adipose tissue from its surface for the entire length of the incision and about $2 \mathrm{~cm}$ in breadth. An approximately $1 \mathrm{~cm}$ longitudinal incision was made in the rectus sheath in the midline and laterally this incision extended transversely about $3-4 \mathrm{~cm}$ on either side superiorly as well as inferiorly beyond the lateral margin of the rectus muscle. Thus two strips of the rectus fascia were produced (Figure 1) with free medial margins which were secured with silk no.1 with the thread kept long on both the sides. Peritoneal cavity was approached in the usual way and abdominal packing done followed by identification of the vault (Figure 2: made easy because of vaginal packing initially) which was then held with Allis' forceps at both of its angles. Peritoneum between these Allis' forceps over the vault was incised. A long curved artey forceps was used to make a track retroperitoneally,parallel to the erstwhile round ligament, exercising utmost care so as to avoid the ureter on the way. On reaching lateral to the rectus muscle the medial margin of the ipsilateral carved rectus sheath strip was held and brought to the angle of the vault, ensuring that no twisting occured. A similar procedure was performed on the opposite side. Once done, the silk threads (kept long earlier), were tied on to the vault with optimal tension (Figure 3). Reperitonisation was done by suturing the incised peritoneum on the vault. Patients with an enterocoele were treated by the Moschowitz operation (4). In those six patients having stress incontinence, concomitant pubovaginal sling repair was carried out. Abdomen was closed in layers after securing haemostasis and removing the sponge pack. Sub-cuticular sutures were applied in all cases. Vaginal packing done prior to surgery was removed. In cases with a rectocele, perineorrhaphy with levator myorrhaphy was done followed by vaginal packing for $24 \mathrm{hrs}$ in such cases. Intravenous fluids were continued for 24 hours and Injectable antibiotics for 36 hours. Oral Fluids were offered after 24 hours. Patients were made ambulatory 24-36 hours following surgery. The catheter was removed after 24 hours, except in patients who also underwent anti-incontinence repair when it was taken out after 5 days post-operatively.

\section{Observations}

Mean operating time was approximately 50 minutes. In those cases in whom only anterior abdominal wall colpopexy was done the procedure was accomplished in 45 minutes, but in those cases in whom additional surgical procedures were required, such as Moschowitz/ Burch/perineorrhaphy, an extra 15 minutes were taken but the duration of surgery never extended beyond 70 minutes. Intraoperative difficulties encountered

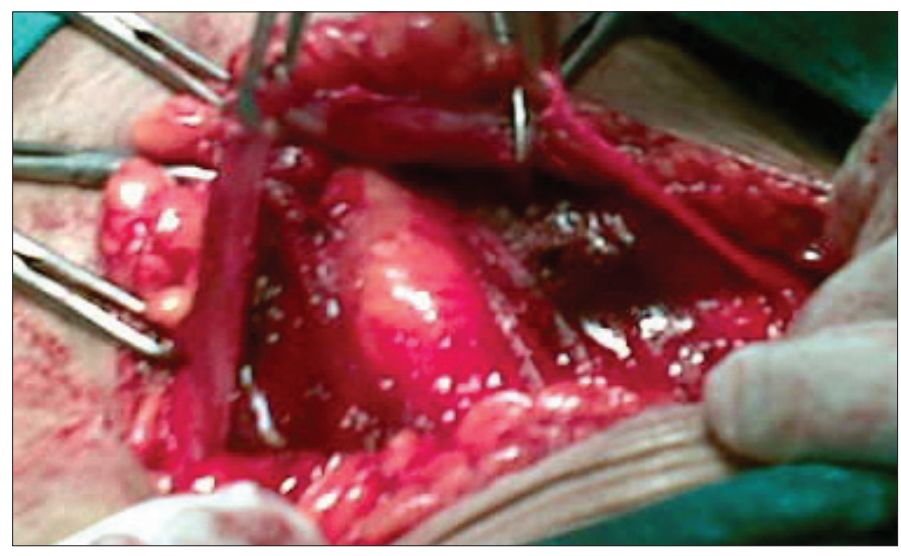

Figure 1. Rectus fascia strips

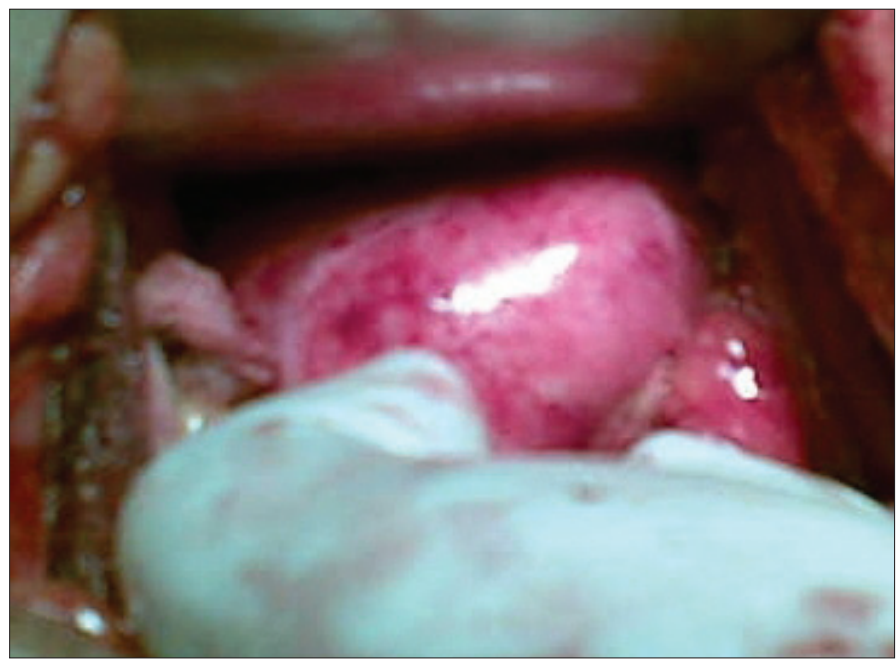

Figure 2. Vault as seen in the abdominal cavity (easily identified due to pre-op intravaginal packing)

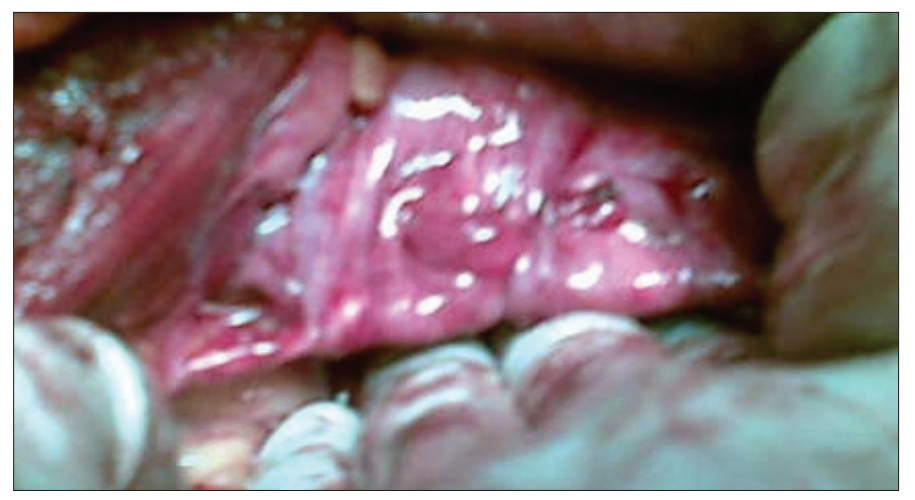

Figure 3. Pulled-up vault after repair with retroperitoneal rectus fascia strips

were not very serious: 3 cases had omental and 1 had small gut adhesions on the vault. Amount of intraoperative blood loss was between 200 to $450 \mathrm{ml}$ (more loss in cases where perineorrhaphy was also done); nevertheless no blood transfusion was required in any of the cases either intra-op. or post-operatively In the post-operative period, one patient (3.7\%) had vomiting on the $2^{\text {nd }}$ day, another $(3.7 \%)$ had fever. $33 \%(n=9)$ of patients felt 
slight tightness in the abdomen but not amounting to discomfort or concern.One patient (3.7\%) who had a simultaneous urinary anti-incontinence operation had urinary retention following removal of the indwelling catheter on the $5^{\text {th }}$ post-operative day and had to be re-catheterised for another 48hrs and toning-up of the bladder carried out.One patient had bleeding from the perineorrhaphy wound on removal of the vaginal pack but not such as to cause concern. 21 patients were discharged 3 days after surgery, those six cases who had concomitant a pubovaginal sling for stress incontinence were discharged 5 days after surgery and all the patients were recalled on the $7^{\text {th }}$ day for removal of sub-cuticular abdominal wound stitches. One patient who had retention of urine was re-admitted for $72 \mathrm{hrs}$. At discharge, per-speculum examination was conducted and the success criteria considered was That, on straining, the vault which was pre-operatively prolapsing was seen to be pulled up/retracting. 18 (66\%) patients are under regular follow-up, (longest follow-up-6yrs 8 months and shortest follow-up of 4yrs 4 months), 9 patients were lost after initial follow-ups and all these patients confirm the success of the procedure. None of the patients showed recurrence of the symptoms.

\section{Discussion}

The incidence of vault prolapse is uncertain but appears to be increased five fold after vaginal hysterectomy (5). The incidence in our institute appears to be marginally better than the quoted one (2), being about $7.8 \%$ of hysterectomies performed vaginally for prolapse and $1.2 \%$ of those performed abdominally for other indications Conservative measures include pelvic floor exercises and different type of pessaries.There is no evidence to suggest that pelvic floor exercises are helpful in vault prolapse (6). Conservative measures may be used to treat this condition in women unfit for surgery or those who require symptomatic relief while awaiting surgery (5). Correction of apical defect remains a surgical challenge-suspension of the vaginal apex is the keystone of surgical repair for pelvic organ prolapse.There are many surgical procedures for treating post-hysterectomy vaginal vault prolapse. The treatment route may be vaginal or abdominal (7). Anterior and posterior vaginal wall repair along with obliteration of the enterocoele sac are inadequate for post-hysterctomy vaginal vault prolapse: this standard repair operation does not support the vaginal vault, and there are risks of vaginal narrowing and shortening and thus dyspareunia (8). Vaginal repair often results in a narrowed and shortened vagina with diminished function (9). Moreover, posterior vaginal sling experience in elderly patients yields poor results (10). The established surgical options lie between a vaginal sacrospinous fixation or an abdominal procedure such as sacrocolpopexy or vault suspension operation (5). Complications of sacrospinous fixation included blood loss, bladder injury, rectovaginal haematoma and vaginal pain, and that of sacrocolpopexy blood loss, bladder injury, incisional hernia, mesh rejection, and wound infection (11). In another study sacrospinous fixation was associated with significantly more intraoperative blood loss, longer catheterisation and hospital stay and more sexual dysfunction (12). Moreover it has a higher failure rate (13).
There is a significantly higher incidence of recurrent vault prolapse and recurrent stress incontinence in the vaginal group (14). In anterior abdominal wall colpopexy using autogenous strips of rectus fascia to repair post-hyst prolapse of the vaginal vault, preservation of a physiologically useful vagina and vaginal caliber and depth were secured and no recurrence arose (15). Successful use of rectus sheath tendon flap was performed in 20 patients with vaginal vault prolapse with minimal complications (16). A comparative study of abdominal colpopexy using rectus fascia and sacral fixation for the treatment of prolapsed vagina following hysterectomy was performed-the abdominal approach yields better results (17). Although augmentation by foreign material is not altogether a new concept, the introduction of commercial kits make mesh procedures more standardized but not necessarily technically easier to perform (18). Recently, a study was carried out involving hitching the vault with a synthetic tape inserted along the lines of the round ligaments and fastened to the external oblique aponeurosis (19). However, use of mesh is associated with infection (20). In patients who are additionally incontinent, an anti-incontinence procedure such as Burch colposuspension or pubo-vaginal sling is usually performed at the same time (20). The role of prophylactic surgery for occult stress incontinence is unclear (21). All pelvic floor defects should be identified to enable surgical repair of significant and potential defects (22). The great variety of techniques described indicate that there is disagreement about the ideal route or technique to be used (7).

\section{Conclusion}

No doubt greater awareness at the time of the original hysterectomy may be the better solution in reducing the incidence of vault prolapse. Nevertheless, anterior abdominal wall colpopexy using autogenous strips of rectus fascia is a simple operation,for repair of post-hysterectomy prolapse of the vaginal vault providing the desirable result of preserving a physiologically useful vagina with normal caliber and depth; moreover,there is no recurrence in follow-up. This anterior abdominal wall colpopexy is a safe operation with low morbidity and longstanding good results with patient satisfaction and can be recommended for sexually active women.

\section{Conflict of interest}

Authors declare that there is no conflict of interest.

\section{Acknowledgement}

M.M. Educational Trust

\section{References}

1. Abrams P, Cardozo L, Fall M, Griffiths D, Rosier P, Ulmesten U, et al. Standardisation Sub-Committee of the International Continence Society. The standardization of terminology of lower urinary tract function: Report from the standardization sub-committee of the International Continence Society. Neurourol Urodyn 2002; 21: 167-78.

2. Marchionni M, Bracco GL, Checcucci V, Carabaneanu A, Coccia EM, Mecacci E, et al. True incidence of vaginal vault prolapse. Thirteen years experience. J Reprod Med 1999; 44: 679-84. 
3. Maher C, Baessler K, Glazener CM, AdamsEJ, Hagen S. Surgical management of pelvic organ prolapse in women. Cochrane Database Syst Rev 2004; 4: CD004014.

4. Steven D, Kleeman, Karram MM. Vaginal vault prolapse. In: Rock JA, Jones HWIII, editors. Te Linde's Operative Gynecology. New Delhi, India: Wolters Kluwer; 2009.p.911-35.

5. Barrington JW, Edwards G. Posthysterectomy vault prolapsed. Int Urogynecol J Pelvic Floor Dysfunct.2000; 11: 241-5.

6. Hagen S, Stark D, Maher C, Adams E. Conservative management of pelvic organ prolapse in women. Cochrane Database Syst REV 2006; 4: CD003882.

7. Girao MJ, Wakavaiach VM, Sartori Mg, Baracat EC, de Lima GR. Rectus fascia colpopexy in posthysterectomy vaginal prolapse: analysis of 18 cases. Int Urogynecol J Pelvic Floor Dysfunct. 1997; 8: 25-8.

8. Toozs-Hobson P, Boos K, Cardozo L. Management of vaginal vault prolapse. BJOG 1998; 105: 13-7.

9. Geomini PM, Brolmann HA, van Binsbergen NJ, Mol BW. Vaginal vault suspension by abdominal sacral colpopexy for prolapse: a follow up study of 40 patients. Eur J Obstet Gynecol Reprod Biol. 2001; 94: 234-8.

10. Mattox TF, Moore S, Stanford EJ, Mills BB. Posterior vaginal sling experience in elderly patients yields poor results. American Journal of Obstetrics and Gynecology. 2006; 194: 1462-6.

11. Maher CF, Qatawneh AM, Dwyer PL, Carey MP, Cornish A, Schulter PJ. Abdominal sacral colpopexy or vaginal sacrospinous colpopexy for vaginal vault prolapse:a prospective randomized study. Am J Obstet Gynecol 2004; 190: 20-6.

12. Lo TS, Wang AC. Abdominal colposacropexy and sacrospinous ligamnent suspension for severe uterovaginal prolapse:a comparison. J Gynecol Surg 1998; 14: 59-64.
13. Brubaker L, Bump R, Fynes M, Jacquetin B, Karram M, Kreder $\mathrm{K}$, et al. Surgery for pelvic organ prolapse. In:Abrams P,Cardozo L,Khoury S,Wein A,editors.Incontinence.3rd ed Paris: Health Publications; 2005.p. 1371-402.

14. Sze EH, Kohli N, Miklos JR, Roat T, Karram MM. A retrospective comparison of abdominal sacrocolpopexy with Burch colposuspension versus sacrospinous fixation with transvaginal needle suspension for the management of vaginal vault prolapsed and coexisting stress incontinence.Int Urogynaecology J Pelvic Floor Dysfunc 1999; 10: 390-3.

15. de Lima OA, Valente CA. Rectus fascia colpopexy for complete prolapsed of the vaginal vault after hysterectomy. Int Surg. 1987; 72: 119-23.

16. Jenkins DT, Stuart J, McCoubrie. Vault prolapse: A new approach. ANZ J of Surgery. 2008; 62: 805-8.

17. Traiman P, De Luca LA, Silva AA, Antonini R, Dias R, Rodrigues JR. Abdominal colpopexy for complete prolapse of the vagina. Int Surg. 1992; 77: 91-5.

18. Flam F, Soderberg MW. New concepts and trends in vaginal prolapse surgery. Acta Obstetricia et Gynecologica Scandinavica. 2009; 88: 251-4.

19. Thursz AD. A method of treating vaginal vault prolapse. BJOG. 2005; 77: 1041-2.

20. Wille S, Braun M, Heidenreich A, Hofmann R, Engelmann U. Sacral Colpopexy with Concurrent Burch Colposuspension in Patients with Vaginal Vault Prolapse. Urol Int 2006; 76: 339-44.

21. Wall LL, Hewitt JK. Urodynamic characteristics of women with complete posthysterectomy vaginal vault prolapse. Urology 1994 ; 44: 336-41.

22. Colombo M, Milani R. Sacrospinous ligament fixation and modified McCall culdoplasty during vaginal hysterectomy for advanced uterovaginal prolapse. Am J Obstet Gynecol. 1998; 79: 13-20. 